\title{
Native and microwaved bean and pea starch preparations: physiological effects on the intestinal ecosystem, caecal tissue and serum lipids in rats
}

\author{
Urszula Krupa-Kozak*, Jerzy Juśkiewicz, Małgorzata Wronkowska, Maria Soral-Śmietana \\ and Zenon Zduńczyk \\ Division of Food Science, Institute of Animal Reproduction and Food Research of the Polish Academy of Sciences, \\ Tuwima 10 str., 10-747 Olsztyn, Poland
}

(Received 23 March 2009 - Revised 6 October 2009 - Accepted 21 October 2009 - First published online 23 December 2009)

Dietary beans and peas provide fibre, resistant starch and other nutrients that are often lacking in the human diet. The influence of native starches of beans and peas (and microwaved preparations) on $\mathrm{N}$ utilisation, biochemical indices in blood serum and caecal ecosystem state (SCFA, bacterial enzymes, micro-organisms) was studied in vivo. The native pea starch contained more resistant starch compared with its bean counterpart (31 v. $17 \%$ ); however, processing decreased these amounts to 25 v. $10 \%$. N digestibility was found to decrease considerably in all experimental groups. A considerable reduction was observed in glucose and total cholesterol concentration in rat blood serum as a result of feeding both dietary legume starch preparations under microwave treatment. This indicates that starch of bean origin activated glycolytic bacterial enzymes; however, all the analysed starches were found to reduce the activity of $\beta$-glucuronidase. In addition, both dietary bean starches significantly induced the formation of SCFA in the caecal digesta. As compared with the control group, a significant decrease in the pH of caecal and colonic digesta was demonstrated for both bean starch preparations. In comparison with the diet with native pea starch, its microwaved preparation reduced the concentrations of acetic, butyric and propionic acids among caecal SCFA and increased the $\mathrm{pH}$ of caecal and colonic digesta. The atherogenic index was significantly lower in rats fed microwaved pea starch. All investigated starch preparations increased the population of Bifidobacterium spp. in caecal digesta, but were also good substrates for opportunistic Enterococcus or Escherichia coli.

Bean and pea starches: Physiological indices: Bacterial enzyme activity: SCFA: Caecal bacteria

Bean and pea seeds are an excellent source of proteins, mono-, oligo- and polysaccharides and several micronutrients, including minerals ${ }^{(1)}$. In addition, bean seeds are rich in dietary fibre and resistant starch $(\mathrm{RS})^{(2)}$, and researchers have suggested that the primary mechanism responsible for metabolic improvement, including benefits in lipids and glycaemic management, is fermentation of RS within the large intestine $^{(1,3)}$. Bean seeds contain a wide range of biologically active constituents that have beneficial, antioxidative, antiinflammatory or detoxification properties, and thus may act as preventative agents against certain metabolic diseases ${ }^{(4)}$.

Carbohydrates should not be treated simply as the energetic component of a diet, but also as a component with potential human health benefits ${ }^{(5,6)}$. Many opinions on healthy eating favour increasing the proportion of legume-based polymeric plant carbohydrates, including starch, in the $\operatorname{diet}^{(7)}$. Starch content in legumes is high and ranges from $22 \%$ up to $45 \%{ }^{(4)}$. Although starch is assumed to be digested completely in the upper gastrointestinal tract, the presence of a particular starch that is resistant to digestion, namely $\mathrm{RS}$, has been recognised ${ }^{(8)}$. According to Asp et al. ${ }^{(5)}$ : 'Resistant starch is the sum of starch and products of starch degradation not absorbed in the small intestine of healthy individuals'. RS possesses beneficial properties, such as stimulating the growth of favourable intestinal bacterial strains ${ }^{(8)}$, and simultaneously increasing the production of SCFA during the colon fermentation process ${ }^{(9)}$, thus positively affecting the environment of the lower part of the gastrointestinal tract.

Studies show that a diet containing NSP and oligosaccharides from peas and beans that are fermented by large-bowel microflora produce a distinct shift in the pattern of SCFA in the caecal content in rats, with an increase in the molar proportion of butyrate ${ }^{(10)}$. Evidence from in vitro studies indicates that butyrate may be anti-neoplastic, since it suppresses the growth of tumour cells and induces apoptosis ${ }^{(11)}$. Some beneficial properties of RS have also been proved in in vivo studies. Van Munster et al. ${ }^{(12)}$ have shown favourable effects of RS on mucosal proliferation in volunteers.

Although it is well documented that processing techniques (soaking, steam cooking, autoclaving, parboiling, baking, extrusion cooking, pyroconversion, microwave irradiation) may affect both the gelatinisation and retrogradation processes, influencing RS formation ${ }^{(2,6)}$, less is known about the effects of such treatments on physiological status.

Abbreviations: cfu, colony-forming units; HDL-C, HDL-cholesterol; MBS, microwaved bean starch; MPS, microwaved pea starch; NBS, native bean starch; NPS, native pea starch; RS, resistant starch.

* Corresponding author: Dr Urszula Krupa-Kozak, fax +48 8952401 24, email u.krupa-kozak@pan.olsztyn.pl 
Because a number of physiological effects in the lower parts of the gastrointestinal tract have been ascribed to RS, the aim of the present study was to evaluate the influence of dietary native bean starch (NBS) and native pea starch (NPS), or their microwaved preparations, on large-bowel parameters, microbial growth, bacterial enzyme activity and SCFA production in vivo in rats.

\section{Materials and methods}

\section{Materials of study}

The present study used commercial pea starch (Cosucra S.A., Warcoing, Belgium) and bean starch isolated on a laboratory scale from bean seeds (Phaseolus vulgaris) cultivar Laponia (Plantico, Poland). Modified forms of the starches were also used. To obtain modified pea starch, native starch of $30 \%$ moisture content underwent $20 \mathrm{~min}$ of microwave processing at $650 \mathrm{~W}$ (microwaved pea starch; MPS). Bean starch was isolated from non-processed beans, or microwaved bean seeds at a 1:3 ratio with water, for $30 \mathrm{~min}$ at $650 \mathrm{~W}$, according to the Soral-Śmietana method ${ }^{(13)}$ (microwaved bean starch; MBS). Briefly, starch was extracted from bean seeds ground into flour by three rinses with distilled water, at 1:6 (w/v), followed by a double extraction with $0.1 \% \mathrm{NaOH}$ at 1:6 (w/v). Starch was adjusted to $\mathrm{pH} 7$ and recovered from each extraction with a $10 \mathrm{~min}$ centrifugation at $1800 \mathrm{~g}$. Starch preparations were freeze-dried, ground and passed through a $160 \mu \mathrm{m}$ sieve.

\section{Chemical analysis of material}

The basic chemical characteristics, total $\operatorname{starch}^{(14)}$, total proteins and ash were determined according to the AOAC method $^{(15)}$. The RS content was determined for native and modified bean and pea starches according to the method of Champ et al. ${ }^{(16)}$.

\section{Feeding experiment}

All animal procedures and handling were conducted with special care in compliance with the guidelines of the Institutional Laboratory Animal Care and Use Committee, University of Warmia and Mazury Olsztyn, Poland. Experiments were conducted on forty-five Wistar rats, aged 4 weeks, in experimental groups of nine male rats. Animals were housed individually under standard conditions: temperature $21-22^{\circ} \mathrm{C}$, relative air humidity $50-70 \%, 12 \mathrm{~h}$ light-dark cycle, intensive ventilation (air turnover fifteen times per $\mathrm{h}$ ) and ad libitum access to water and food. The nutritional experiment lasted 6 weeks. The composition of the five experimental diets is presented in Table 1 . The diets contained about $13.5 \%$ total protein. In the experimental diets, $30 \%$ of the maize starch was substituted with native or modified bean or pea starches. To accommodate the different protein content of the starch preparations, all diets were made iso-nitrogenous by the addition of appropriate amounts of soyabean protein isolate. After the experiment, the rats were anaesthetised with sodium pentobarbitone according to the recommendations for euthanasia of experimental animals ${ }^{(17)}$.
Table 1. Composition of experimental diets with native or modified bean or pea starches

\begin{tabular}{lccccc}
$\begin{array}{l}\text { Diet composition } \\
\text { (g/100 g DM) }\end{array}$ & Control & NBS & MBS & NPS & MPS \\
\hline NBS & - & 30 & - & - & - \\
MBS & - & - & 30 & - & - \\
NPS & - & - & - & 30 & - \\
MPS & - & - & - & - & 30 \\
Casein* & 4.96 & 4.96 & 4.96 & 4.96 & 4.96 \\
Soya protein isolate† & 9.9 & 9.9 & 6.32 & 9.9 & 9.9 \\
DL-Methionine & 0.2 & 0.2 & 0.2 & 0.2 & 0.2 \\
Cellulose & 5 & 5 & 5 & 5 & 5 \\
Soya oil§ & 4 & 4 & 4 & 4 & 4 \\
Lard\| & 4 & 4 & 4 & 4 & 4 \\
Cholesterol & 0.5 & 0.5 & 0.5 & 0.5 & 0.5 \\
Mineral mix & 3.5 & 3.5 & 3.5 & 3.5 & 3.5 \\
Vitamin mix†† & 1 & 1 & 1 & 1 & 1 \\
Maize starch $\ddagger \ddagger$ & 66.94 & 36.94 & 40.52 & 36.94 & 36.94 \\
\hline
\end{tabular}

NBS, native bean starch; MBS, microwaved bean starch; NPS, native pea starch; MPS, microwaved pea starch.

${ }^{*}$ Casein preparation containing $89.7 \%$ protein, $0.3 \%$ fat, $2.0 \%$ ash and $8.0 \%$ water (Lacpol Co., Murowana Goslina, Poland).

† Soya protein isolate - SPI Procon 2100 IP (Solae Co., St Louis, MO, USA).

$\ddagger \alpha$-Cellulose (Sigma, Poznan, Poland)

$\S$ Kruszwica SA Co., Kruszwica, Poland

II Morliny SA, Animex Co., Ostroda, Poland.

I Sigma, Poznan, Poland.

** AIN-93G-MX ${ }^{(49)}$ (per kg mix): $357 \mathrm{~g}$ calcium carbonate anhydrous $(40.04 \%$ $\mathrm{Ca}) ; 196 \mathrm{~g}$ potassium phosphate monobasic $(22.76 \% \mathrm{P}, 28.73 \% \mathrm{~K}) ; 70.78 \mathrm{~g}$ potassium citrate, tripotassium monohydrate $(36.16 \% \mathrm{~K}) ; 74 \mathrm{~g}$ sodium chloride $(39.34 \% \mathrm{Na}, 60.66 \% \mathrm{Cl}) ; 46.6 \mathrm{~g}$ potassium sulfate $(44.87 \% \mathrm{~K}, 18.39 \% \mathrm{~S}) ; 24 \mathrm{~g}$ magnesium oxide $(60.32 \% \mathrm{Mg}) ; 6.06 \mathrm{~g}$ ferric citrate $(16.5 \% \mathrm{Fe}) ; 1.65 \mathrm{~g}$ zinc carbonate $(52.14 \% \mathrm{Zn}) ; 1.45 \mathrm{~g}$ sodium meta-silicate. $9 \mathrm{H}_{2} \mathrm{O}(9.88 \% \mathrm{Si}) ; 0.63 \mathrm{~g}$ manganous carbonate $(47.79 \% \mathrm{Mn}) ; 0.3 \mathrm{~g}$ cupric carbonate $(57.47 \% \mathrm{Cu})$; $0.275 \mathrm{~g}$ chromium potassium sulfate. $12 \mathrm{H}_{2} \mathrm{O}(10.42 \% \mathrm{Cr}) ; 81.5 \mathrm{mg}$ boric acid $(17.5 \% \mathrm{~B}) ; 63.5 \mathrm{mg}$ sodium fluoride $(45.24 \% \mathrm{~F}) ; 31.8 \mathrm{mg}$ nickel carbonate $(45 \%$ $\mathrm{Ni}) ; 17.4 \mathrm{mg}$ lithium chloride $(16.38 \% \mathrm{Li}) ; 10.25 \mathrm{mg}$ sodium selenate anhydrous $(41.79 \% \mathrm{Se}) ; 10 \mathrm{mg}$ potassium iodate $(59.3 \% \mathrm{I}) ; 7.95 \mathrm{mg}$ ammonium paramolybdate $.4 \mathrm{H}_{2} \mathrm{O}(54.34 \% \mathrm{Mo}) ; 6.6 \mathrm{mg}$ ammonium vanadate $(43.55 \% \mathrm{~V})$; $221.026 \mathrm{~g}$ powdered sucrose.

††AIN-93G-VM(49) $(\mathrm{g} / \mathrm{kg} \mathrm{mix}): 3.0$ nicotinic acid; 1.6 calcium pantothenate; 0.7 pyridoxine- $\mathrm{HCl} ; 0.6$ thiamin- $\mathrm{HCl} ; 0.6$ riboflavin; 0.2 folic acid; 0.02 biotin; 2.5 vitamin $B_{12}$ (cyanocobalamin, $0.1 \%$ in mannitol); 15.0 vitamin $E$ (all-rac$\alpha$-tocopheryl acetate, $500 \mathrm{IU} / \mathrm{g}$ ); 0.8 vitamin A (all-trans-retinyl palmitate, $500000 \mathrm{lU} / \mathrm{g}$ ); 0.25 vitamin $\mathrm{D}_{3}$ (cholecalciferol, $400000 \mathrm{IU} / \mathrm{g}$ ); 0.075 vitamin $\mathrm{K}_{1}$ (phylloquinone); 974.655 powdered sucrose.

拉ebe, Veendam, Holland.

\section{Indices of intake and utilisation of diet}

Body-weight gain and feed intake of rats were determined individually throughout the study. The coefficients of apparent $\mathrm{N}$ digestibility and retention were calculated in the first period of experimental feeding from daily $\mathrm{N}$ intake and $\mathrm{N}$ excretion in faeces or in faeces and urine, respectively. Faeces and urine were collected from eight rats in each group for $5 \mathrm{~d}$, preceded by the initial $10 \mathrm{~d}$ preliminary period. $\mathrm{N}$ in the samples was determined for each rat according to the Kjeldahl method ${ }^{(15)}$.

\section{Physiological indices of the caecum}

After laparotomy, blood samples were taken from the tail vein, and then the caecum and colon with contents were removed and weighed. As soon as possible after killing (less than $10 \mathrm{~min}$ ), samples of fresh digesta were used for immediate analysis of DM, ammonia and SCFA, and the remainder was transferred to tubes and stored at $-70^{\circ} \mathrm{C}$. The caecal and colonic walls were flushed clean with ice-cold saline, blotted on filter paper and weighed for tissue mass. 
The caecal and colonic $\mathrm{pH}$ was measured using a microelectrode and a $\mathrm{pH} /$ ion meter (model 301; Hanna Instruments, Vila do Conde, Portugal). The dry mass of caecal contents was determined after drying at $105^{\circ} \mathrm{C}$ to determine the constant weight. In fresh caecal digesta, ammonia was extracted and trapped in a solution of boric acid in Conway's dishes, and determined by direct titration with sulfuric acid ${ }^{(18)}$. Bacterial enzyme activity in the caecal digesta was measured by the rate of $p$ - or $o$-nitrophenol release from nitrophenylglucosides according to the method of Djouzi \& Andrieux ${ }^{(19)}$, modified by Juśkiewicz \& Zduńczyk ${ }^{(20)}$. The following substrates were used: for $\beta$-glucuronidase, $p$-nitrophenyl- $\beta$-D-glucuronide; for $\alpha$-galactosidase, $\quad p$-nitrophenyl- $\alpha$-D-galactopyranoside; for $\beta$-galactosidase, $o$-nitrophenyl- $\beta$-D-galactopyranoside; for $\alpha$-glucosidase, $p$-nitrophenyl- $\alpha$-D-glucopyranoside; for $\beta$ glucosidase, $p$-nitrophenyl- $\beta$-D-glucopyranoside. The reaction mixture contained $0.3 \mathrm{ml}$ of substrate solution $(5 \mathrm{~mm})$ and $0.2 \mathrm{ml}$ of a $1: 10(\mathrm{v} / \mathrm{v})$ dilution of the caecal sample in $100 \mathrm{~mm}$-phosphate buffer $(\mathrm{pH} 7 \cdot 0)$ after centrifugation at $10000 \mathrm{~g}$ for $15 \mathrm{~min}$. Incubation was carried out at $37^{\circ} \mathrm{C}$ and $p$ - or $o$-nitrophenol was quantified at $\lambda=400 \mathrm{~nm}$ and at $\lambda=420 \mathrm{~nm}$, respectively, after the addition of $2.5 \mathrm{ml}$ $0 \cdot 25 \mathrm{M}$-cold sodium carbonate. Enzymic activity of $\alpha$ - and $\beta$-glucosidases, $\alpha$ - and $\beta$-galactosidases, and $\beta$-glucuronidase was expressed as $\mu$ mol product formed per min (unit) per $g$ digesta in the fresh caecal sample.

The caecal contents were analysed for SCFA concentration by GC: Shimadzu GC-14A chromatograph (Shimadzu, Kyoto, Japan) equipped with $2.5 \mathrm{~m} \times 2.6 \mathrm{~mm}$ glass column, containing $10 \% \mathrm{SP}-1200 / 1 \% \mathrm{H}_{3} \mathrm{PO}_{4}$ on $80 / 100$ Chromosorb W AW (Supelco, Bellefonte, PA, USA); column temperature $110^{\circ} \mathrm{C}$; flame ionisation detector (FID) temperature $180^{\circ} \mathrm{C}$; injection temperature $195^{\circ} \mathrm{C}$. The caecal content $(0.2 \mathrm{~g})$ was mixed with $0.2 \mathrm{ml}$ formic acid, diluted with deionised water and centrifuged at $10000 \mathrm{~g}$ for $5 \mathrm{~min}$, and the supernatant fraction was decanted for injection into the column of the gas chromatograph. The caecal SCFA pool was calculated as the concentration of SCFA in the caecum $(\mu \mathrm{mol} / \mathrm{g})$ multiplied by the mass of caecal contents (g) and was expressed as $\mu$ mol per $100 \mathrm{~g}$ body mass.

\section{Determination of bacteria in caecal contents}

The number of selected bacteria groups in caecal contents was determined using selective or diversifying media in appropriate incubation conditions. Fresh caecal contents were collected directly from each rat, weighed and immediately homogenised with $1 \%$ peptone in water $(0.5 \%(\mathrm{w} / \mathrm{v})$ meat peptone - Peptobak; BTL, Łódź, Poland); and $0.5 \%(\mathrm{w} / \mathrm{v})$ pancreatic hydrolysate of casein $(\mathrm{pH} 7 \cdot 0$, bio-Trypcase; bioMérieux, Marcy-l'Etoile, France). After dispersion, serial decimal dilutions were made, avoiding aeration.

The live cell number of bifidobacteria was counted on modified nutrient Garche's agar ${ }^{(21)}$ after incubation at $37^{\circ} \mathrm{C}$ for $48 \mathrm{~h}$ in anaerobic conditions (AnaeroGen ${ }^{\mathrm{TM}}$; Oxoid, Basingstoke, Hants, UK) ${ }^{(22)}$. Identification was based on appearance of colonies, specific morphology of cells checked under phase contrast with microscope Microphoto FXA (Nikon, Tokyo, Japan), and the presence of fructose6-phosphate phosphoketolase $(E C 4.1 .2 .22)^{(23)}$, which is specific for bifidobacteria. The number of Lactobacillus spp. was counted on de Man-Rogosa-Sharpe (MRS) medium ${ }^{(24)}$ incubated at $37^{\circ} \mathrm{C}$ for $72 \mathrm{~h}$ in microaerophilic conditions (double medium layer). Coliforms were counted on MacConkey agar medium incubated at $37^{\circ} \mathrm{C}$ for $24 \mathrm{~h}$ in aerobic conditions ${ }^{(25)}$, and Enterococcus was counted on medium with canamycin, esculin and sodium azide (Oxoid) at $37^{\circ} \mathrm{C}$ after $24 \mathrm{~h}$ in aerobic conditions.

\section{Blood serum analysis}

Blood samples collected from tail veins were left for $1 \mathrm{~h}$ at room temperature to aggregate erythrocytes. Blood serum was purified by centrifugation at $2500 \mathrm{~g}$ for $15 \mathrm{~min}$ at $4^{\circ} \mathrm{C}$, and stored at $-70^{\circ} \mathrm{C}$ after freezing with liquid $\mathrm{N}_{2}$. Concentrations of the following metabolites were determined in the blood serum: TAG (catalogue no. 220-200; ChF Reagents, Warsaw, Poland), glucose (catalogue no. 210-200; ChF Reagent), total cholesterol (catalogue no. 150-200; ChF Reagent) and HDL-cholesterol (HDL-C) fraction (catalogue no. 160-100; ChF Reagent). Log (TAG/HDL-C) was calculated as atherogenic index of serum ${ }^{(26)}$.

\section{Statistical analysis}

Results of the chemical composition of the investigated starches are reported as mean values and standard deviations. Results of the physiological response of the treated animals are expressed as mean values with their pooled standard error. Statistical comparisons were done transversely between different dietary groups. The statistical significance of particular indices determined for different dietary groups was analysed by one-way ANOVA, with one factor (diet) followed by the inspection of all differences between pairs of means with Duncan's multiple-range test. Differences having $P$ values lower than 0.05 were considered to be statistically significant. Calculations were made with STATISTICA 6.0 (StatSoft Corporation, Kraków, Poland).

Bacterial numbers are expressed as log colony-forming units (cfu) per $1 \mathrm{~g}$ caecal digesta. Arithmetic means of rats in groups and significance of differences among groups were calculated using Student's $t$ test for non-numerous groups.

\section{Results}

The chemical composition of native and modified bean and pea starches is presented in Table 2. Hydrothermal treatment of bean seeds caused the formation of starch-protein complexes that influenced the chemical composition of the obtained preparation of bean starch. Modified starch obtained from microwaved bean seeds was characterised by a very high protein content and an increased mineral content compared with NBS. Native commercial pea starch was of high purity and contained only negligible amounts of proteins and mineral compounds. Taking into consideration the RS content, meaningful differences were ascertained between NBS and NPS. The amount of RS was about two times higher in NPS than in NBS. After microwave irradiation of pea starch and bean seeds, in the modified pea and bean starch preparations that were obtained, a RS content decrease was observed. 
Table 2. Chemical composition of native and modified bean and pea starches (\% DM)* (Mean values and standard deviations)

\begin{tabular}{|c|c|c|c|c|c|c|c|c|}
\hline & \multicolumn{2}{|c|}{$\begin{array}{l}\text { Total starch } \\
\text { (\% DM) }\end{array}$} & \multicolumn{2}{|c|}{$\mathrm{RS}(\% \mathrm{DM})$} & \multicolumn{2}{|c|}{$\begin{array}{l}\text { Total proteins } \\
\text { (\% DM) }\end{array}$} & \multicolumn{2}{|c|}{ Ash (\% DM) } \\
\hline & Mean & SD & Mean & SD & Mean & SD & Mean & SD \\
\hline Native bean starch & 82.92 & 2.54 & $17 \cdot 19$ & 0.80 & 1.50 & 0.02 & 0.58 & 0.02 \\
\hline Microwaved bean starch & $79 \cdot 38$ & 1.25 & $10 \cdot 47$ & 0.45 & $10 \cdot 54$ & 0.06 & 1.22 & 0.02 \\
\hline Native pea starch & 85.45 & 1.98 & 31.53 & 1.45 & 0.48 & 0.01 & 0.07 & 0.01 \\
\hline Microwaved pea starch & 85.50 & 2.04 & $25 \cdot 81$ & 1.26 & 0.42 & 0.02 & 0.08 & 0.01 \\
\hline
\end{tabular}

RS, resistant starch.

${ }^{*}$ Results are average values from three replications.

The addition of starch applied in the study was stipulated based on our previous investigations and corrected based on the total protein content of the whole composition of constituents.

Nutritional indices were determined in experimental rats fed diets containing $30 \%$ bean or pea starch preparations before and after microwave treatment (Table 3). Partial substitution of maize starch by the experimental starches had no significant effect on the diet intake. Substitution of the diet with the MBS preparation caused a significant decrease in body-weight gain compared with the control animals. This effect was not observed in the MPS preparation. Evaluation of $\mathrm{N}$ excretion patterns showed significant differences among experimental groups (Table 3). Compared with the control group, the amount of $\mathrm{N}$ excreted in the faeces of rats fed a diet with bean starch increased considerably $(P<0.05)$, while the amount excreted in urine was reduced only insignificantly $(P<0 \cdot 05)$. Pea starch added to the diet also induced an increase in $\mathrm{N}$ excreted in faeces, but the effect was less pronounced than with bean starch. On the other hand, dietary pea starch, especially when microwaved, significantly $(P<0.05)$ decreased urine $\mathrm{N}$ content. The highest $\mathrm{N}$ digestibility was found in the control group, while all groups fed diets containing bean or pea starch showed a significant lowering of this index. As compared with NBS, the preparation of bean isolated from microwaved bean seeds, as a starch-protein complex, did not influence the apparent digestibility of $\mathrm{N}$. The apparent digestibility of $\mathrm{N}$ in rats fed
MPS was significantly higher than in those fed diets supplemented with NPS.

In rats fed bean starch, the fluctuation of $\mathrm{N}$ excretion between faeces and urine resulted in a balanced value of $\mathrm{N}$ retention in the body, comparable with the control group. A significantly higher coefficient of apparent $\mathrm{N}$ retention was found in the group fed MPS (Table 3).

Changes in the physiological response of the caecum and colon as a result of dietary substitution with bean or pea starch are presented in Table 4. In general, the masses of caecal tissue and digesta in the experimental groups were similar to the control group fed maize starch. A significant increase in the caecal tissue and a significant bulk of caecal digesta were observed only in the case of the rats fed the MBS preparation. MPS did not induce similar changes. All rats fed experimental diets had a similar dry mass of caecal digesta $(21.4-22.5 \%)$. Compared with the control group, the groups receiving diets with both bean starches and NPS showed a significant decrease in caecal ammonia concentration $(0.381$ v. $0.243-0.295 \mathrm{mg} / \mathrm{g}$ digesta). MPS caused a highly significant increase in ammonia concentration in the digesta $(0.477 \mathrm{mg} / \mathrm{g}$ digesta). The administration of diets containing bean starch was accompanied by a significant decrease in $\mathrm{pH}$ of caecal digesta compared with the control group. The intake of NPS similarly caused an increase in caecal digesta acidity, while the MPS diet did not change the caecal $\mathrm{pH}$ compared with the control. Experimental treatments, regardless of the type of starch, did not affect

Table 3. Nutritional indices and nitrogen balance in rats fed diets with native or modified bean or pea starches (Mean values and pooled standard errors)

\begin{tabular}{|c|c|c|c|c|c|c|}
\hline & \multicolumn{5}{|c|}{ Diet } & \multirow[b]{2}{*}{$\mathrm{SEM}^{*}$} \\
\hline & Control & NBS & MBS & NPS & MPS & \\
\hline Diet intake (g/6 weeks) & 628 & 598 & 599 & 600 & 632 & $6 \cdot 96$ \\
\hline Body-weight gain (g/6 weeks) & $202^{\mathrm{a}}$ & $191^{\mathrm{a}, \mathrm{b}}$ & $187^{b}$ & $194^{\mathrm{a}, \mathrm{b}}$ & $203^{\mathrm{a}}$ & $3 \cdot 22$ \\
\hline$N$ intake $(g / 5 d)$ & $1 \cdot 70^{\mathrm{a}, \mathrm{b}}$ & $1 \cdot 68^{a, b}$ & $1 \cdot 81^{\mathrm{a}}$ & $1.63^{\mathrm{b}}$ & $1 \cdot 70^{\mathrm{a}, \mathrm{b}}$ & 0.02 \\
\hline$N$ in faeces $(m g / 5 d)$ & $82 \cdot 1^{\mathrm{c}}$ & $144^{\mathrm{a}}$ & $150^{\mathrm{a}}$ & $101^{\mathrm{b}}$ & $91 \cdot 5^{\mathrm{b}, \mathrm{c}}$ & 4.31 \\
\hline $\mathrm{N}$ in urine $(\mathrm{mg} / 5 \mathrm{~d})$ & $594^{\mathrm{a}}$ & $542^{\mathrm{a}, \mathrm{b}}$ & $542^{\mathrm{a}, \mathrm{b}}$ & $516^{\mathrm{b}}$ & $486^{b}$ & $10 \cdot 1$ \\
\hline $\mathrm{N}$ apparent digestibility (\%)† & $95 \cdot 2^{\mathrm{a}}$ & $91.5^{\mathrm{d}}$ & $91 \cdot 7^{d}$ & $93 \cdot 8^{\mathrm{c}}$ & $94 \cdot 6^{\mathrm{b}}$ & 0.23 \\
\hline $\mathrm{N}$ retention $(\%) \ddagger$ & $60 \cdot 0^{\mathrm{b}}$ & $59 \cdot 1^{\mathrm{b}}$ & $61 \cdot 7^{\mathrm{ab}}$ & $62 \cdot 1^{\mathrm{a}, \mathrm{b}}$ & $65 \cdot 9^{\mathrm{a}}$ & 0.64 \\
\hline
\end{tabular}

NBS, native bean starch; MBS, microwaved bean starch; NPS, native pea starch; MPS, microwaved pea starch.

a,b,c,d Mean values within a row with unlike superscript letters were significantly different $(P<0.05)$.

* Standard error of the means (standard deviation for all rats divided by square root of rat number, $n 45$ ).

† Apparent digestibility: ( $\mathrm{N}$ intake $-\mathrm{N}$ faecal/ $\mathrm{N}$ intake) $\times 100$.

$\ddagger$ Retention: ( $\mathrm{N}$ intake $-\mathrm{N}$ faecal $-\mathrm{N}$ urinary/N intake) $\times 100$ 
Table 4. Physiological parameters of caecum and colon of rats fed diets with native or modified bean or pea starches (Mean values and pooled standard errors)

\begin{tabular}{|c|c|c|c|c|c|c|}
\hline & \multicolumn{5}{|c|}{ Diet } & \multirow[b]{2}{*}{ SEM $^{*}$} \\
\hline & Control & NBS & MBS & NPS & MPS & \\
\hline Caecal tissue (g/100 g BW) & $0.272^{b}$ & $0.285^{\mathrm{b}}$ & $0.343^{a}$ & $0.267^{b}$ & $0.289^{b}$ & 0.007 \\
\hline Caecal digesta ( $\mathrm{g} / 100 \mathrm{~g} \mathrm{BW})$ & $1 \cdot 22^{b}$ & $1.02^{\mathrm{b}}$ & $1.65^{\mathrm{a}}$ & $1 \cdot 15^{\mathrm{b}}$ & $1 \cdot 19^{\mathrm{b}}$ & 0.055 \\
\hline DM of digesta (\%) & $22 \cdot 9$ & $22 \cdot 1$ & $22 \cdot 0$ & 21.4 & $22 \cdot 5$ & 0.366 \\
\hline Ammonia (mg/g digesta) & $0.381^{\mathrm{b}}$ & $0.295^{c}$ & $0.243^{c}$ & $0.287^{\mathrm{C}}$ & $0.477^{\mathrm{a}}$ & 0.013 \\
\hline $\mathrm{pH}$ of caecal contents & $6 \cdot 94^{\mathrm{a}}$ & $6 \cdot 46^{\mathrm{b}, \mathrm{c}}$ & $6 \cdot 40^{\mathrm{C}}$ & $6 \cdot 62^{b}$ & $6 \cdot 85^{\mathrm{a}}$ & 0.039 \\
\hline Colonic tissue (g/100 g BW) & $0.483^{b}$ & $0.474^{\mathrm{b}}$ & $0.519^{a}$ & $0.455^{\mathrm{b}}$ & $0.455^{\mathrm{b}}$ & 0.012 \\
\hline Colonic digesta ( $\mathrm{g} / 100 \mathrm{~g} \mathrm{BW})$ & 0.570 & 0.548 & 0.550 & 0.501 & 0.542 & 0.026 \\
\hline $\mathrm{pH}$ of colonic contents & $6 \cdot 58^{a}$ & $5 \cdot 75^{\mathrm{d}}$ & $5 \cdot 85^{\mathrm{d}}$ & $6 \cdot 01^{\mathrm{c}}$ & $6 \cdot 23^{\mathrm{b}}$ & 0.047 \\
\hline
\end{tabular}

NBS, native bean starch; MBS, microwaved bean starch; NPS, native pea starch; MPS, microwaved pea starch; BW, body weight.

a,b,c,d Mean values within a row with unlike superscript letters were significantly different $(P<0.05)$.

* Standard error of the means (standard deviation for all rats divided by square root of rat number, $n$ 45).

the colon digesta mass (Table 4). In comparison with the control group, the $\mathrm{pH}$ of colonic contents was significantly lower in all treatments, especially in the groups fed NBS.

The highest activity of all investigated glycolytic bacterial enzymes, $\alpha$ - and $\beta$-glucosidase, as well as $\alpha$ - and $\beta$-galactosidase, was found in rats fed NBS, whereas the activities of all enzymes were similar to controls in rats fed NPS (Table 5). The MBS preparation caused a significant decrease in the activity of both galactosidases and both glucosidases compared with NBS, with values resembling those reported for the control diet. MPS did not cause significant changes in the activity of examined bacterial enzymes, except for $\alpha$-glucosidase, whose activity was significantly lower than the group fed NPS. The highest activity of $\beta$-glucuronidase in caecal contents was recorded in the control group, and the most pronounced decrease was found in the rats fed MBS. This effect was less noticeable in the case of both NBS and NPS, as well as MPS $(P<0.05 v$. control).

Compared with the control group, a diet substituted with either NBS or MBS significantly increased the total SCFA concentration in the caecal digesta (Table 6). Specifically, an increase in acetic and butyric acids and a simultaneous decrease in valeric and iso-acids were observed. When the $\mathrm{C}_{2}: \mathrm{C}_{3}: \mathrm{C}_{4}$ profile is considered, diets containing bean starch reduced the proportion of acetic and propionic acids $(P<0.05)$ and increased the percentage of butyric acid $(P<0.05)$, compared with the control group. Starch isolated from microwaved bean seeds had no influence on caecum SCFA concentration and profile, but significantly affected the caecal SCFA production (pool). Compared with the control and the other diets, MBS had a significantly higher total SCFA pool. This applied also to the major acids: acetic, propionic and butyric acids. Moreover, the groups receiving MBS had a significantly greater butyric acid pool than the control rats $(P<0 \cdot 05)$. Both pea starch preparations were associated with significant differences in the concentration and production of individual acids. The concentration and production of analysed SCFA were significantly reduced in the caecal contents of rats fed MPS, except for iso-acids, which remained at the level observed in the NPS treatment. For the $\mathrm{C}_{2}: \mathrm{C}_{3}: \mathrm{C}_{4}$ profile, the bacterial fermentation of MPS resulted in a higher proportion of acetate and a lower proportion of butyrate compared with the group that was fed NPS. The SCFA profile reported for rats from the MPS group was similar to that of the control group.

The counts of caecal bacterial groups in rats fed native or modified bean and pea starches were analysed. The microflora of control group rats showed a high number of Lactobacillus spp. (over $9 \log$ cfu/g faeces) and Bifidobacterium spp. (8.2 log cfu/g faeces), followed by Escherichia coli and Enterococcus spp. There was no statistically significant difference $(P<0.05)$ between experimental groups with respect to Lactobacillus counts. Generally, their mean number was slightly lower than the control, except for the diet containing NBS. In all diets containing bean or pea starches, the growth of the Bifidobacterium population was

Table 5. Caecum bacterial enzyme activity of rats fed the control diet (with maize starch) or diets with native or modified bean or pea starches

(Mean values and pooled standard errors)

\begin{tabular}{lllllll}
\hline & \multicolumn{5}{c}{ Diet } \\
\cline { 2 - 5 } & Control & NBS & MBS & NPS & MPS & SEM $^{*}$ \\
\hline$\alpha$-Glucosidase (U/g caecal contents) $\dagger$ & $0.99^{\mathrm{b}, \mathrm{c}}$ & $1.54^{\mathrm{a}}$ & $0.94^{\mathrm{b}, \mathrm{c}}$ & $1.20^{\mathrm{b}}$ & $0.87^{\mathrm{c}}$ & 0.052 \\
$\beta$-Glucosidase (U/g caecal contents) $\dagger$ & $0.39^{\mathrm{b}}$ & $0.55^{\mathrm{a}}$ & $0.33^{\mathrm{b}}$ & $0.39^{\mathrm{b}}$ & $0.38^{\mathrm{b}}$ & 0.022 \\
$\alpha$-Galactosidase (U/g caecal contents) $\dagger$ & $0.62^{\mathrm{b}}$ & $1.43^{\mathrm{a}}$ & $0.83^{\mathrm{b}}$ & $0.96^{\mathrm{b}}$ & $0.68^{\mathrm{b}}$ & 0.071 \\
$\beta$-Galactosidase (U/g caecal contents) $\dagger$ & $2 \cdot 40^{\mathrm{b}}$ & $3.74^{\mathrm{a}}$ & $2 \cdot 36^{\mathrm{b}}$ & $2 \cdot 71^{\mathrm{b}}$ & $2 \cdot 20^{\mathrm{b}}$ & $0 \cdot 150$ \\
$\beta$-Glucuronidase (U/g caecal contents) $\dagger$ & $3.13^{\mathrm{a}}$ & $2 \cdot 86^{\mathrm{a}, \mathrm{b}}$ & $1.63^{\mathrm{b}}$ & $2 \cdot 31^{\mathrm{a}, \mathrm{b}}$ & $2 \cdot 29^{\mathrm{a}, \mathrm{b}}$ & $0 \cdot 178$
\end{tabular}

NBS, native bean starch; MBS, microwaved bean starch; NPS, native pea starch; MPS, microwaved pea starch.

a,b,c Mean values within a row with unlike superscript letters were significantly different $(P<0.05)$.

* Standard error of the means (standard deviation for all rats divided by square root of rat number, $n 45$ ).

$\dagger 1 \mathrm{U}=1 \mu \mathrm{mol}$ product formed per min. 
Table 6. Content of SCFA in the caecal contents of rats fed the control diet (with maize starch) or diets with native or modified bean or pea starches

(Mean values and pooled standard errors)

\begin{tabular}{|c|c|c|c|c|c|c|}
\hline & \multicolumn{5}{|c|}{ Diet } & \multirow[b]{2}{*}{ SEM $^{*}$} \\
\hline & Control & NBS & MBS & NPS & MPS & \\
\hline \multicolumn{7}{|c|}{ SCFA ( $\mu \mathrm{mol} / \mathrm{g}$ caecal contents) } \\
\hline Acetic & $65 \cdot 9^{\mathrm{b}, \mathrm{c}}$ & $78 \cdot 2^{\mathrm{a}}$ & $78 \cdot 5^{\mathrm{a}}$ & $70 \cdot 3^{a, b}$ & $56 \cdot 9^{c}$ & 1.687 \\
\hline Propionic & $13 \cdot 3^{a}$ & $12 \cdot 7^{\mathrm{a}}$ & $12 \cdot 6^{\mathrm{a}}$ & $13 \cdot 1^{\mathrm{a}}$ & $10 \cdot 1^{b}$ & 0.375 \\
\hline Iso-butyric & $1 \cdot 15^{\mathrm{a}}$ & $0.53^{\mathrm{b}, \mathrm{c}}$ & $0.33^{c}$ & $0.63^{b}$ & $0.67^{b}$ & 0.047 \\
\hline Butyric & $9 \cdot 10^{\mathrm{C}}$ & $25 \cdot 3^{\mathrm{a}}$ & $24 \cdot 0^{\mathrm{a}}$ & $16 \cdot 0^{\mathrm{b}}$ & $7 \cdot 60^{\mathrm{C}}$ & 1.233 \\
\hline Iso-valeric & $1.60^{\mathrm{a}}$ & $0.60^{c, d}$ & $0.38^{d}$ & $0.82^{b, c, d}$ & $1 \cdot 14^{\mathrm{a}, \mathrm{b}}$ & 0.086 \\
\hline Valeric & $1 \cdot 61^{\mathrm{a}}$ & $1.44^{\mathrm{a}, \mathrm{b}}$ & $1 \cdot 39^{\mathrm{a}, \mathrm{b}}$ & $1.57^{\mathrm{a}}$ & $1 \cdot 20^{\mathrm{b}}$ & 0.046 \\
\hline Total SCFA & $92 \cdot 7^{\mathrm{c}}$ & $119^{a}$ & $117^{\mathrm{a}}$ & $102^{b, c}$ & $77 \cdot 6^{\mathrm{d}}$ & $2 \cdot 851$ \\
\hline \multicolumn{7}{|c|}{ Profile $\mathrm{C}_{2}: \mathrm{C}_{3}: \mathrm{C}_{4}$} \\
\hline $\mathrm{C}_{2}$ & $71^{\mathrm{a}, \mathrm{b}}$ & $66^{c}$ & $67^{c}$ & $69^{b, c}$ & $73^{\mathrm{a}}$ & 0.607 \\
\hline $\mathrm{C}_{3}$ & $14^{\mathrm{a}}$ & $11^{\mathrm{b}}$ & $11^{\mathrm{b}}$ & $13^{a, b}$ & $13^{\mathrm{a}, \mathrm{b}}$ & 0.318 \\
\hline $\mathrm{C}_{4}$ & $10^{c}$ & $21^{\mathrm{a}}$ & $20^{\mathrm{a}}$ & $16^{\mathrm{b}}$ & $10^{c}$ & 0.803 \\
\hline \multicolumn{7}{|c|}{ SCFA pool $(\mu \mathrm{mol} / 100 \mathrm{~g} \mathrm{BW})$} \\
\hline Acetic & $79 \cdot 6^{\mathrm{b}}$ & $78 \cdot 6^{\mathrm{b}}$ & $127^{\mathrm{a}}$ & $81 \cdot 0^{\mathrm{b}}$ & $67 \cdot 1^{\mathrm{c}}$ & 4.029 \\
\hline Propionic & $16 \cdot 2^{a, b}$ & $13 \cdot 2^{\mathrm{b}}$ & $20 \cdot 4^{\mathrm{a}}$ & $15 \cdot 2^{a, b}$ & $11.9^{\mathrm{b}}$ & 0.790 \\
\hline Iso-butyric & $1.43^{\mathrm{a}}$ & $0.55^{\mathrm{b}}$ & $0.53^{b}$ & $0.75^{\mathrm{b}}$ & $0 \cdot 78^{\mathrm{b}}$ & 0.066 \\
\hline Butyric & $11 \cdot 1^{c}$ & $25 \cdot 1^{\mathrm{b}}$ & $40 \cdot 9^{\mathrm{a}}$ & $18 \cdot 7^{\mathrm{b}, \mathrm{c}}$ & $9 \cdot 21^{c}$ & $2 \cdot 105$ \\
\hline Iso-valeric & $1.96^{\mathrm{a}}$ & $0.62^{\mathrm{a}, \mathrm{b}}$ & $0.63^{b}$ & $0.96^{\mathrm{b}}$ & $1 \cdot 33^{\mathrm{a}, \mathrm{b}}$ & 0.118 \\
\hline Valeric & $1.96^{a, b}$ & $1.45^{\mathrm{b}}$ & $2 \cdot 25^{a}$ & $1.85^{\mathrm{a}, \mathrm{b}}$ & $1.42^{\mathrm{b}}$ & 0.096 \\
\hline Total & $112^{\mathrm{b}}$ & $120^{\mathrm{b}}$ & $191^{\mathrm{a}}$ & $118^{\mathrm{b}}$ & $91 \cdot 8^{\mathrm{c}}$ & 6.599 \\
\hline
\end{tabular}

NBS, native bean starch; MBS, microwaved bean starch; NPS, native pea starch; MPS, microwaved pea starch; BW, body weight.

a,b,c,d Mean values within a row with unlike superscript letters were significantly different $(P<0.05)$.

* Standard error of the means (standard deviation for all rats divided by square root of rat number, $n 45$ ).

higher than in the control group. In caecal material of rats fed NPS, the count of Bifidobacterium reached $8.86 \mathrm{log} \mathrm{cfu} / \mathrm{g}$ and was significantly higher than in the control group. In the experimental groups fed bean or pea starch, the $E$. coli count exceeded the control group; however, the difference was statistically significant only for rats fed MPS. Diets containing NBS or NPS created favourable conditions for the growth of Enterococcus spp. that were significantly different from the control group.

Serum biochemical indices determined by in vivo experiments on rats fed bean or pea starch are presented in Table 7. Generally, the blood serum glucose concentration of rats fed all experimental diets was lower than in the control group. Statistically significant differences were noted in rats fed MBS, and NPS or MPS. The TAG level in the serum of experimental rats was lower than in the control animals; however, the differences between groups were insignificant due to high intra-group variations. The lowest TAG concentration was observed in the group fed the diet containing MPS. Bean starch, regardless of hydrothermal processing, significantly reduced the total cholesterol concentration without lowering the HDL-cholesterol fraction. As a result, the proportion of HDL-C to the total cholesterol was significantly higher in the NBS and MBS groups than in the control. The cholesterol profile observed for the NPS group was similar to that of the control. Rats fed MPS had about $30 \%$ lower total cholesterol as well as similar HDL-C blood levels as the rats fed NPS. The proportion of HDL-C to the total cholesterol was significantly higher in the MPS group than in the NPS group. The atherogenic index of serum, log (TAG/HDL-C), was significantly lower in the MPS group compared with other treatments $(P<0 \cdot 05)$.

Table 7. Biochemical indices of serum of rats fed diets with native or modified bean or pea starches

(Mean values and pooled standard errors)

\begin{tabular}{lcccccc}
\hline & \multicolumn{5}{c}{ Diet } \\
\cline { 2 - 5 } & Control & NBS & MBS & NPS & MPS & SEM $^{*}$ \\
\hline Glucose (mmol/l) & $14.43^{\mathrm{a}}$ & $13.76^{\mathrm{a}, \mathrm{b}}$ & $12.43^{\mathrm{b}, \mathrm{c}}$ & $12.43^{\mathrm{b}, \mathrm{c}}$ & $11.38^{\mathrm{c}}$ & 0.273 \\
TAG (mmol/l) & 1.932 & 1.797 & 1.808 & 1.808 & 1.232 & 0.105 \\
Total cholesterol (mmol/l) & $3.911^{\mathrm{a}}$ & $3.263^{\mathrm{b}}$ & $3.134^{\mathrm{b}}$ & $3.937^{\mathrm{a}}$ & $3.341^{\mathrm{b}}$ & 0.071 \\
HDL-C (mmol/l) & 1.166 & 1.243 & 1.140 & 1.062 & 1.140 & 0.023 \\
HDL-C/total cholesterol (\%) & $30^{\mathrm{b}}$ & $38^{\mathrm{a}}$ & $36^{\mathrm{a}}$ & $27^{\mathrm{b}}$ & $34^{\mathrm{a}}$ & 0.451 \\
Log (TAG/HDL-C) & $0.220^{\mathrm{a}}$ & $0.160^{\mathrm{a}}$ & $0.200^{\mathrm{a}}$ & $0.231^{\mathrm{a}}$ & $0.034^{\mathrm{b}}$ & 0.004 \\
\hline
\end{tabular}

NBS, native bean starch; MBS, microwaved bean starch; NPS, native pea starch; MPS, microwaved pea starch; HDL-C HDL-cholesterol.

${ }^{a, b, c}$ Mean values within a row with unlike superscript letters were significantly different $(P<0 \cdot 05)$

* Standard error of the means (standard deviation for all rats divided by square root of rat number, $n 45$ ). 


\section{Discussion}

Current research often focuses on finding food features that prevent disease or enhance wellbeing. FAO/WHO recommendations ${ }^{(27)}$ indicate an important role for carbohydrates, including starch and dietary fibre, of which a valuable source is legume seeds. At this point, special attention should be paid to the environment of lower parts of the gastrointestinal tract, and associated implications for the systemic response of the host. Therefore, the main aim of the present study was combining biochemical analysis with in vivo physiological experiments, to assess the wider influence of native or modified bean and pea starches in the diet on the function of the rat gastrointestinal tract.

Analysis of the chemical composition of legume starches showed that the examined NBS and NPS were similar to those characterised in other studies ${ }^{(28,29)}$, with respect to the content of the main components. Tovar \& Melito ${ }^{(30)}$ ascertained that processing legumes may induce the formation of RS. However, microwave treatment of bean and pea starches resulted in a significant reduction of RS content, which was in agreement with the results obtained in a previous study $^{(31)}$. It has also been reported that moist heat processing and microwave irradiation may lead to significant changes in starch susceptibility to enzymic digestion ${ }^{(32,33)}$. Niba \& Hoffman $^{(34)}$ observed that autoclaving and parboiling increased rapidly digestible starch levels in most examined flours (maize, potato, cocoyam, plantain, yam, rice), while microwaving significantly reduced rapidly digestible starch compared with raw flour. It must be assumed that not only RS content, but also amounts of rapidly and slowly digestible starch fractions might have further physiological implications, including those observed in the present study.

A study conducted by Pastuszewska et al. ${ }^{(35)}$ showed that $\mathrm{N}$ excretion patterns were strongly influenced by diet composition, especially different types of dietary carbohydrates. RS, and to some extent slowly digestible starch, by escaping digestion in the small intestine, has few interactions with other components of the upper gastrointestinal tract, but it is fermented in the large intestine which results in the formation of such fermentation products as gases $\left(\mathrm{CO}_{2}, \mathrm{H}_{2}\right.$, methane) and organic acids (lactic acid and SCFA). $\mathrm{N}$ excreted in faeces might be derived from incomplete bacterial digestion of dietary protein, secreted digestive enzymes and sloughed mucosal cells. However, the carbohydrate fractions of a diet constitute the main energy source for bacteria which might increase the utilisation of blood urea carried to the large intestine ${ }^{(36)}$ which, in consequence, leads to an increase in the amount of excreted $\mathrm{N}$ that is mainly of bacterial origin. At the same time, the $\mathrm{N}$ excreted in urine decreased ${ }^{(37)}$. In the present study, adding bean starch preparations to diets increased the amount of $\mathrm{N}$ excreted in faeces, with a simultaneous decrease in the coefficient of apparent $\mathrm{N}$ digestibility, which probably indicates increased bacteria proliferation in the large intestine. These results were also in agreement with an increased concentration and pool of SCFA in the caecum of rats fed diets with bean starch preparations. All experimental groups which received diets substituted with bean starch showed a decrease of $\mathrm{N}$ excreted in urine, resulting in similar $\mathrm{N}$ utilisation values in all bean starch-fed groups.
This indicated that applying microwave processing to bean seeds did not significantly influence the availability of bacterial fermentation substrates reaching the caecum. The hypertrophy of the caecal wall as a result of dietary starch from microwaved bean seeds was also observed in other studies $^{(38)}$. Apart from the effect of SCFA on caecal epithelium, another possible cause of increased epithelium proliferation was indicated in a study by Whiteley et al. ${ }^{(39)}$. These authors found that mucosal volume was correlated with digesta mass rather than with SCFA levels, concluding that physical stretching of the epithelium might be a more important causal factor. Indeed, the caecal tissue mass was well correlated with digesta mass in the present study. It should be assumed that both ways, via SCFA and increased bulk of digesta, overlapping with one another might be involved in differentiated caecal tissue mass.

There is agreement that when feeding single-stomached hosts various carbohydrate sources, the calculated total SCFA pool produced in the caecum provides the most precise information on the effect of the investigated preparation on lower gut fermentation ${ }^{(40)}$. In rats fed diets with MBS, the highest pool of total SCFA, including the three main acids, acetic, propionic and butyric, indicated that this type of starch was a good source of energy for growth of the large intestine bacterial population.

The intensity of fermentation, reflected in $\mathrm{pH}$ values, SCFA concentration and pool, was lower with pea starch, especially MPS. In comparison with NBS, the addition of NPS to the diet decreased the $\mathrm{N}$ excreted in the faeces and urine. Therefore, pea starch seems to be a poorer substrate for large-intestinal microflora than bean starch. This assumption was also verified by a lower concentration of total SCFA, especially butyric acid, and a higher $\mathrm{pH}$ of intestinal digesta in rats fed NPS. MPS additionally decreased the $\mathrm{N}$ loss in faeces and urine, resulting in the highest $\mathrm{N}$ retention index among all experimental groups. The values of other parameters describing the function of the gastrointestinal tract, such as concentration and pool of SCFA, and $\mathrm{pH}$ of caecal digesta, indicated that microwave irradiation of pea starch did not promote the rate of large intestine fermentation.

The NBS group was associated with an increased activity level of bacterial $\alpha$ - and $\beta$-glucosidases as well as $\alpha$ - and $\beta$-galactosidases. Only the activity of bacterial $\beta$-glucuronidase seemed to be unaffected by NBS. The MBS preparation fed to rats favourably reduced the activity of potentially harmful $\beta$-glucuronidase. Such an effect should be considered as beneficial because $\beta$-glucuronidase is believed to be largely responsible for the hydrolysis of glucuronide conjugates in the gut and thus important in the generation of toxic and carcinogenic substances ${ }^{(41)}$. This effect was also observed for diets containing both pea starch preparations.

In addition to modulating microbial metabolic activity, certain dietary preparations containing RS have been proven to possess a selective action on the bacterial composition in the lower parts of the gastrointestinal tract, i.e. raised colonic bifidobacteria numbers have been observed ${ }^{(42)}$. In summary, it was found that an intake of bean and pea starches positively affected the rat caecum microflora. Both native starches, when added to the rat diet, increased the population of beneficial Bifidobacterium spp. and Lactobacillus spp., although they were good substrates for opportunistic 
Enterococcus spp. growth. In contrast, the diet containing MPS stimulated a growth of E. coli in the rat caecum. It is very important to know that a Bifidobacterium population can be multiplied by using bean and pea starches as well as their preparations. This type of bacteria is beneficial for a host body by producing vitamins $\mathrm{B}_{1}, \mathrm{~B}_{2}$ and $\mathrm{K}$, amongst others. In addition, its fermentation metabolite - lactic acid - may inhibit the growth of putrefactive bacteria and enhances the assimilation of $\mathrm{Ca}$ and $\mathrm{Mg}$ ions ${ }^{(43,44)}$. These bacteria produce $\beta$-galactosidase which may hydrolyse lactose and other sugars of bloating properties and incorporate galactose in their structures.

In the present experiment, a considerable reduction in glucose and total cholesterol in almost all experimental treatments was observed. Only for NPS was the total cholesterol level unaffected compared with control animals. Although the dietary treatments did not affect the serum HDL-cholesterol concentration, the proportion of HDL-C to total cholesterol was significantly enhanced by the NBS, MBS and MPS diets. Additionally, MPS led to a $30 \%$ drop in the serum TAG concentration. The atherogenic index of serum was beneficially reduced when the MPS preparation was fed to experimental animals. This index, defined as $\log$ (TAG/HDL-C), has recently been proposed as a marker of plasma/serum atherogenicity because it is increased in subjects at higher risk of CHD and is inversely correlated with the cholesterol in LDL particle size ${ }^{(45)}$. The hypocholesterolaemic effects of preparations containing RS have been amply proven in animal trials, but conclusions from studies on human subjects are rather circumspect when the influence of RS on lipid metabolism is considered ${ }^{(46)}$. In the case of animal experiments, relatively high amounts of dietary $\mathrm{RS}$ were added and it was reported that to explain the effect of RS on serum total cholesterol and TAG concentrations, the hypotheses on the effects of NSP on these markers could be applied to RS preparations as well. Serum cholesterol might have been decreased by $\mathrm{RS}$ as a result of an increased faecal excretion of sterols and inhibited via SCFA of cholesterol synthesis in the liver ${ }^{(47)}$. Serum TAG concentration may be lowered due to the effects on lipid absorption and hepatic fatty acid synthesis ${ }^{(48)}$.

In summary, the present study provides data regarding the beneficial effect of diets supplemented by NBS and NPS or model starch preparations isolated after microwave irradiation of whole bean seeds with excess water or MPS with limited free water on small mammals (rats). The microwave treatment of bean seeds enabled the formation of a starch preparation containing a complex of two bean biopolymer starchproteins. The physiological response of rats to the applied dietary treatments varied depending on the plant source. Partial substitution of maize starch by the experimental starches caused a decrease in body-weight gain compared with the control animals. The bean starch preparation more favourably affected the caecal environment, while a dietaryprocessed pea starch preparation positively changed the serum lipid profile and significantly reduced the atherogenic index of the serum. For both starches and their microwaved preparations, a statistically significant increase of the total SCFA (especially butyric acid) in the caecal digesta was found. They also constitute a good substrate for the growth of a Bifidobacterium population.

\section{Acknowledgements}

M. S. S., M. W., U. K.-K. and J. J. participated in the realisation of grant no. 2P06T 01129 entitled 'Starch of bean and peas seeds and their starch preparations - the study of biological properties using the model experiments on rats' (2005-8). The research was financially supported by the Ministry of Science and Higher Education.

All animal procedures and handling were conducted with special care in compliance with the guidelines of the Institutional Laboratory Animal Care and Use Committee, University of Warmia and Mazury Olsztyn, Poland. Z. Z. is the member of the Institutional Laboratory Animal Care and Use Committee, University of Warmia and Mazury, Olsztyn, Poland. The authors wish to thank Professor Maria Bielecka and the team of the Department of Food Microbiology, Institute of Animal Reproduction and Food Research of the Polish Academy of Sciences, Olsztyn, Poland, for their help in microbial analysis.

M. S. Ś. managed the grant and all authors had full access to all the data in the study and take responsibility for the integrity of the data and the accuracy of analyses. U. K.-K., M. S. S. and Z. Z. were involved in the conception and design of the study. U. K.-K., J. J. and M. W. were involved in the collection and assembly of data, and the analysis and interpretation of the data. J. J. performed the statistical analyses. Critical revision of the manuscript for important intellectual content was completed by all the authors.

The authors declare that there are no conflicts of interest to disclose.

\section{References}

1. Tharanthan RN \& Mahadevamma S (2003) Grain legumes - a boon to human nutrition. Trends Food Sci Tech 14, 507-518.

2. Soral-Śmietana M \& Krupa U (2005) Changes in the macrocomponents and microstructure of white bean seeds upon mild hydrothermal treatment. Czech J Food Sci 23, 74-83.

3. Bassano LA, Jiang H, Ogden LG, et al. (2001) Legume consumption and risk of coronary heart disease in US men and women. Arch Intern Med 161, 2573-2578.

4. Scarafoni A, Magni C \& Duranti M (2007) Molecular nutraceutics as a mean to investigate the positive effects of legume seed proteins on human health. Trends Food Sci Tech 18, 454-463.

5. Asp N-G, van Amelsvoort JMM \& Hautvast JGAJ (1996) Nutritional implications of resistant starch. Nutr Res Rev 9, 1-31.

6. Haralampu SG (2000) Resistant starch - a review of the physical properties and biological impact of RS3. Carbohyd Polym 41, 285-292.

7. Topping DL, Fukushima M \& Bird AR (2003) Resistant starch as a prebiotic and synbiotic: state of the art. Proc Nutr Soc 62, $171-176$.

8. Soral-Śmietana M (2000) Resistant starch - nutritional or nonnutritional component of food. Pol J Food Nutr Sci 9/50, $15-21$.

9. Bird AR \& Topping DL (2001) Resistant starches, fermentation and large bowel health. In Handbook of Dietary Fiber, pp. 147-158 [SS Cho and ML Dreher, editors]. New York: Marcel Dekker.

10. Key FB \& Mathers JC (1995) Digestive adaptations of rats given white bread and cooked haricot beans (Phaseolus vulgaris): large-bowel fermentation and digestion of complex carbohydrates. Br J Nutr 74, 393-406. 
11. Hague A, Butt AJ \& Paraskeva C (1996) The role of butyrate in human colonic epithelial cells: an energy source or inducer of differentiation and apoptosis? Proc Nutr Soc 55, 937-943.

12. Van Munster IP, Tangerman A \& Nagengast FM (1994) Effect of resistant starch on colonic fermentation, bile acid metabolism, and mucosal proliferation. Dig Dis Sci 39, 834-842.

13. Soral-Śmietana M (1993) Charakterystyka fizykochemiczna skrobi bobiku (Physico-chemical charcteristics of faba bean starch; article in Polish with an English abstract). Acta Acad Agricult Tech Olst 25, 137-150.

14. AOAC (1975) Official Method 14.031. In Official Methods of Analysis of AOAC International, 12th ed. [S Williams, editor]. Washington, DC: AOAC.

15. AOAC (1990) Official Method 976.06. In Official Methods of Analysis of AOAC International, 15th ed. [S Williams, editor]. Arlington, VA: AOAC.

16. Champ M, Martin L, Noah L, et al. (1999) Analytical methods for resistant starch. In Complex Carbohydrates in Foods, pp. 184-187 [S Sungsoo Cho, L Prosky and M Dreher, editors]. New York: Marcel Dekker Inc.

17. Close B, Banister K, Baumans V, et al. (1997) Recommendation for euthanasia of experimental animals: part 2. Lab Anim 31, 1-32.

18. Hofirek B \& Haas D (2001) Comparative studies of ruminal fluid collected by oral tube or by puncture of the caudorental ruminal sac. Acta Vet Brno 70, 27-33.

19. Djouzi Z \& Andrieux C (1997) Compared effect of the three oligosaccharides on metabolism of intestinal microflora in rats with a human faecal flora. Br J Nutr 78, 313-324.

20. Juśkiewicz J \& Zduńczyk Z (2004) Effects of cellulose, carboxymethylcellulose and inulin fed to rats as single supplements or in combinations on their caecal parameters. Comp Biochem Physiol A 139, 513-519.

21. Rasic JL (1990) Culture media for detection and enumeration of the bifidobacteria in fermented milk products. IDF Bull 252, 24-34.

22. Teraguchi S, Kawashima T \& Kuboyama M (1982) Test tube method for counting bifidobacteria in commercial dairy and pharmaceutical bacteria products. J Food Hyg Soc Japan 23, 29-35.

23. Scardovi V (1986) Genus Bifidobacterium. In Bergey's Manual of Systematic Bacteriology, pp. 1418-1434 [PHA Sneath, NS Mair, ME Sharpe and JG Holt, editors]. Baltimore, MD: Williams and Wilkins Co.

24. De Man JC, Rogosa M \& Sharpe ME (1960) A medium for the cultivation of lactobacilli. J Appl Bacteriol 23, 130-135.

25. Collins CH, Lyne PM \& Grange JM (1995) Cultura media. In Collins' and Lyne's Microbiological Methods, pp. 60-93 [CH Collins, P Lyne and J Grange, editors]. Oxford, UK: Butterworth-Heinemann.

26. Frohlich J \& Dobiasova M (2003) Fractional esterification rate of cholesterol and ratio of triglycerides to HDL-cholesterol are powerful predictors of positive findings on coronary angiography. Clin Chem 49, 1873-1880.

27. Food and Agriculture Organization \& World Health Organization (1998) Carbohydrates in Human Nutrition. Report of a Joint FAO/WHO Expert Consultation, Rome, 14-18 April 1997. FAO Food and Nutrition Paper no. 66. Rome: FAO.

28. Ratnayake WS, Hoover R, Shahidi F, et al. (2001) Composition, molecular structure and physicochemical properties of starches from four field pea (Pisum sativum L.) cultivars. Food Chem 74, 189-202.

29. Hoover R \& Ratnayake WS (2002) Starch characteristics of black bean, chick pea, lentil, navy bean and pinto bean cultivars grown in Canada. Food Chem 78, 489-498.

30. Tovar J \& Melito C (1996) Steam-cooking and dry heating produce resistant starch in legumes. J Agr Food Chem 44, 2642-2645.

31. Krupa U, Soral-Śmietana M \& Lewandowicz G (2007) Bean starch - chemical and structural changes upon microwave heat-moisture treatment. In Starch. Progress in Basic and Applied Science, pp. 243-254 [P Tomasik, VP Yuryev and E Bertoft, editors]. Cracow: Polish Society of Food Technologists.

32. Lehmann U \& Robin F (2007) Slowly digestible starch - its structure and health implications: a review. Trends Food Sci Tech 18, 346-355.

33. Chung HJ, Liu Q \& Hoover R (2009) Impact of annealing and heat-moisture treatment on rapidly digestible, slowly digestible and resistant starch levels in native and gelatinized corn, pea and lentil starches. Carbohyd Polym 75, 436-447.

34. Niba LL \& Hoffman J (2003) Resistant starch and $\beta$-glucan levels in grain sorghum (Sorghum bicolor M.) are influenced by soaking and autoclaving. Food Chem 81, 113-118.

35. Pastuszewska B, Kowalczyk J \& Ochtabińska A (2000) Dietary carbohydrates affect caecal fermentation and modify nitrogen excretion patterns in rats. II. Studies with diets differing in protein quality. Arch Anim Nutr 53, 335-352.

36. Younes H, Demigne C, Behr S, et al. (1995) Resistant starch exerts a lowering effect on plasma urea by enhancing urea $\mathrm{N}$ transfer into the large intestine. Nutr Res 15, 1199-1210.

37. Juśkiewicz J, Godycka-Kłos I, Matusevičius P, et al. (2006) Influence of pea and lupin oligosaccharides on caecal shortchain fatty acids production and nitrogen excretion patterns in rats. Pol J Food Nutr Sci 15/56, 77-82.

38. Johnson IT \& Gee JM (1986) Gastrointestinal adaptation in response to soluble non-available polysaccharides in the rat. Br J Nutr 55, 497-505.

39. Whiteley LO, Higgins JM, Purdon MP, et al. (1996) Evaluation in rats of the dose-response relationship among colonic mucosal growth, colonic fermentation, and dietary fiber. Dig Dis Sci 41, 1458-1467.

40. Campbell JM, Fahey GC Jr \& Wolf BW (1997) Selected indigestible oligosaccharides affect large bowel mass, caecal and fecal short-chain fatty acids, $\mathrm{pH}$ and microflora in rats. J Nutr 127, 130-136.

41. Pool-Zobel BL, Van Loo J, Rowland IR, et al. (2002) Experimental evidences on the potential of prebiotic fructans to reduce the risk of colon cancer. Br J Nutr 87, 273-281.

42. Bird AR, Vuaran M, Brown I, et al. (2007) Two high-amylose maize starches with different amounts of resistant starch vary in their effects on fermentation, tissue and digesta mass accretion, and bacterial populations in the large bowel of pigs. Br J Nutr 97, 134-144.

43. Gibson GR \& Roberfroid MB (1995) Dietary modulation of the human colonic microbiota: introducing the concept of prebiotics. J Nutr 125, 1401-1412.

44. Bezkorovainy A (1989) Nutrition and metabolism of bifidobacteria. In Biochemistry and Physiology of Bifidobacteria, pp. 93-129 [A Bezkorovainy and R Miller-Catchpole, editors]. Boca Raton, FL: CRC Press Inc.

45. Dobiášová M \& Frohlich J (2001) The plasma parameter log (TG/HDL-C) as an atherogenic index: correlation with lipoprotein particle size and esterification rate in apoB-lipoprotein-depleted plasma $\left(\mathrm{FER}_{\mathrm{HDL}}\right)$. Clin Biochem 34, 583-588.

46. Kishida T, Nogami H, Ogawa H, et al. (2002) The hypocholesterolemic effect of high amylose cornstarch in rats is mediated by an enlarged bile acid pool and increased fecal bile acid excretion, not by cecal fermented products. $J$ Nutr 132, 2519-2524.

47. Nugent AP (2005) Health properties of resistant starch. Nutr Bulletin 30, 27-54.

48. De Deckere EA, Kloots WJ \& Van Amelsvoort JM (1993) Resistant starch decreases serum total cholesterol and triacylglycerol concentrations in rats. J Nutr 123, 2142-2151.

49. Reeves PG (1997) Components of the AIN-93 diets as improvements in the AIN-76A diet. J Nutr 127, 838-841. 